
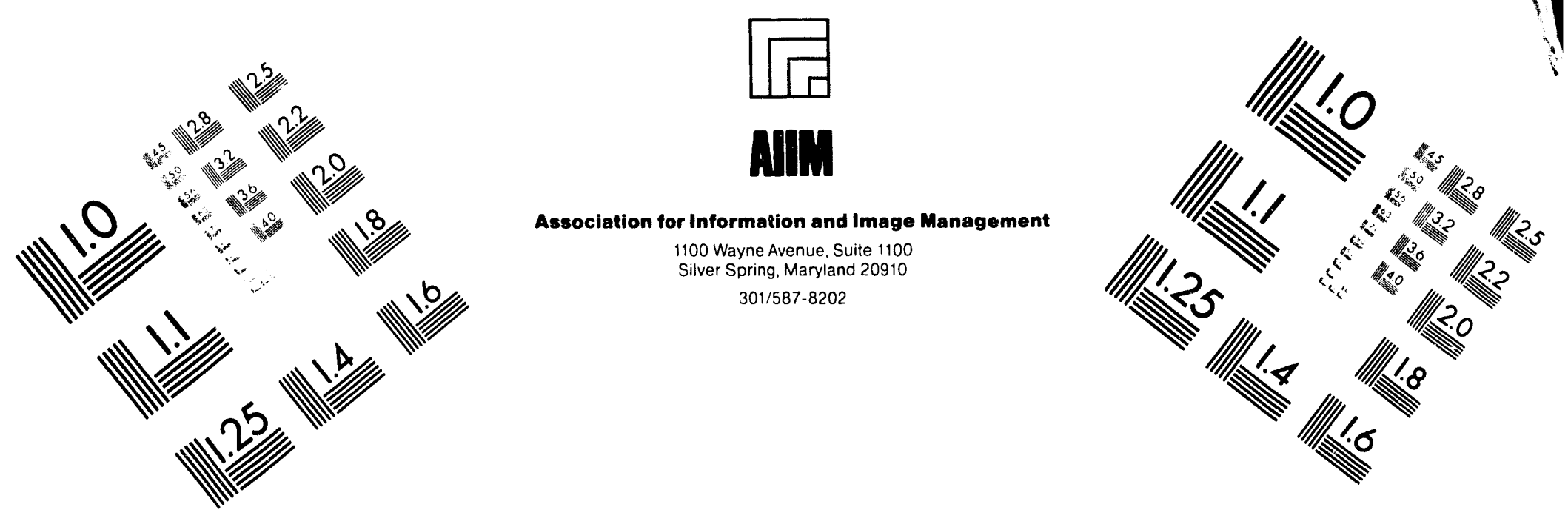

Centimeter

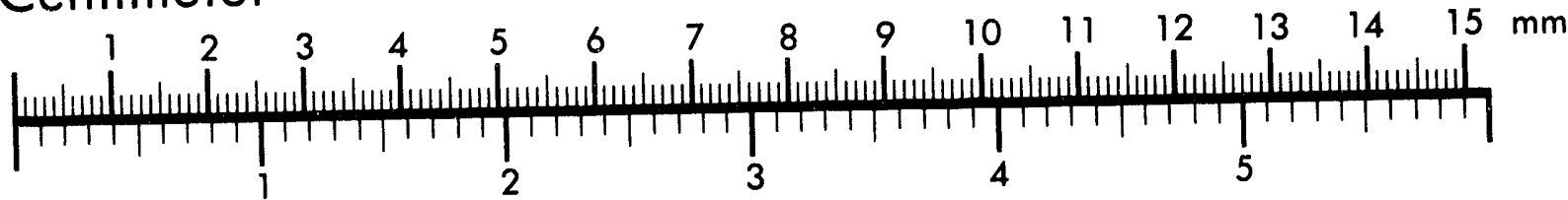

l.iches
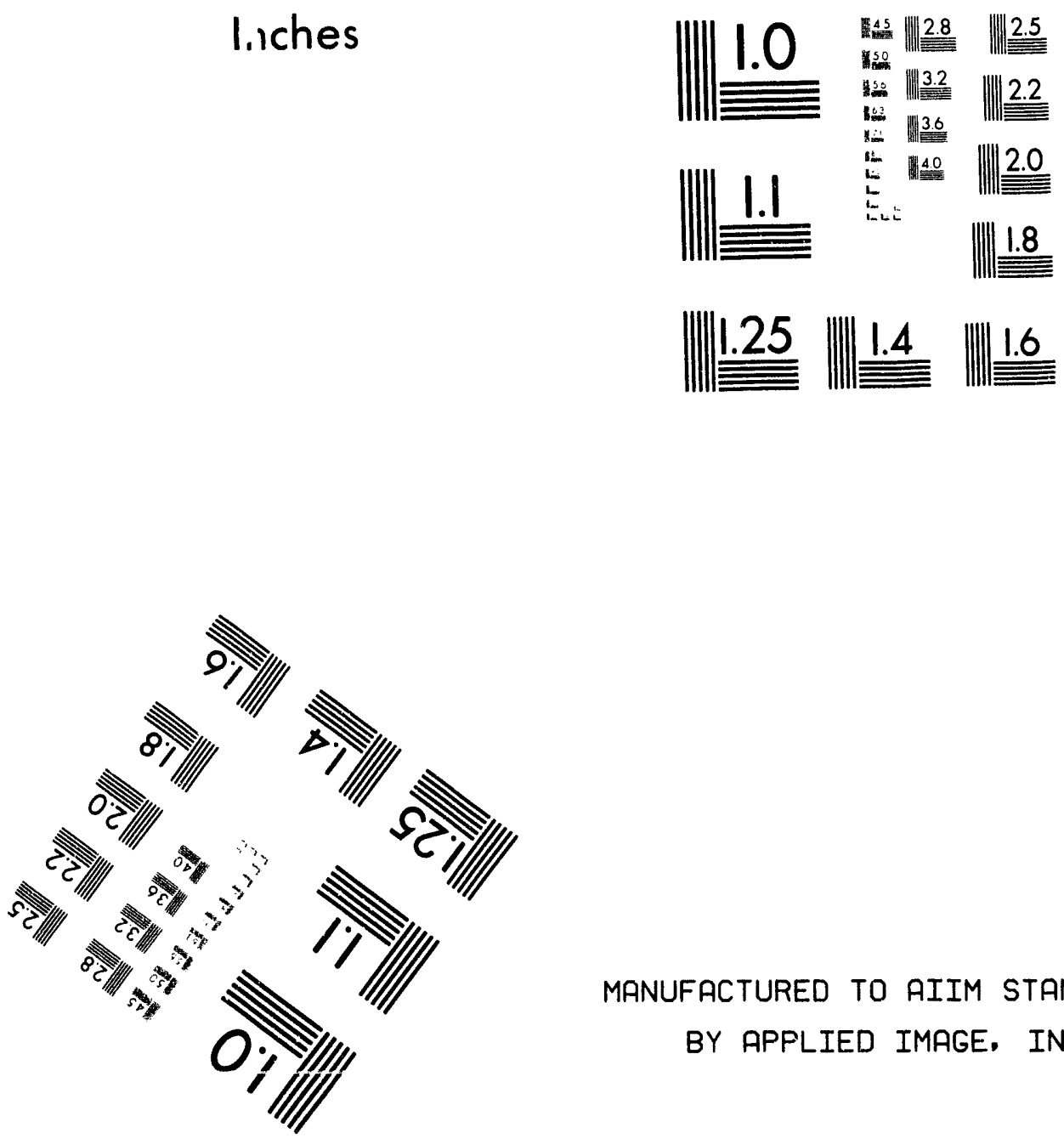

MANUFACTURED TO AIIM STANDARDS

BY APPLIED IMAGE. INC.

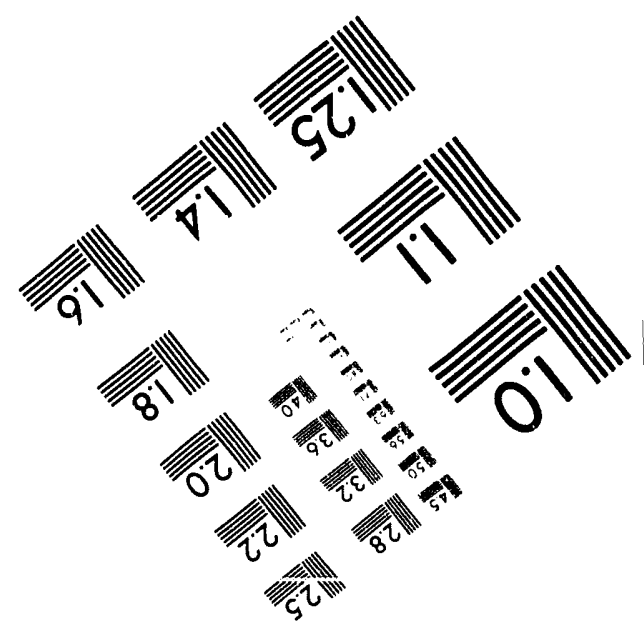



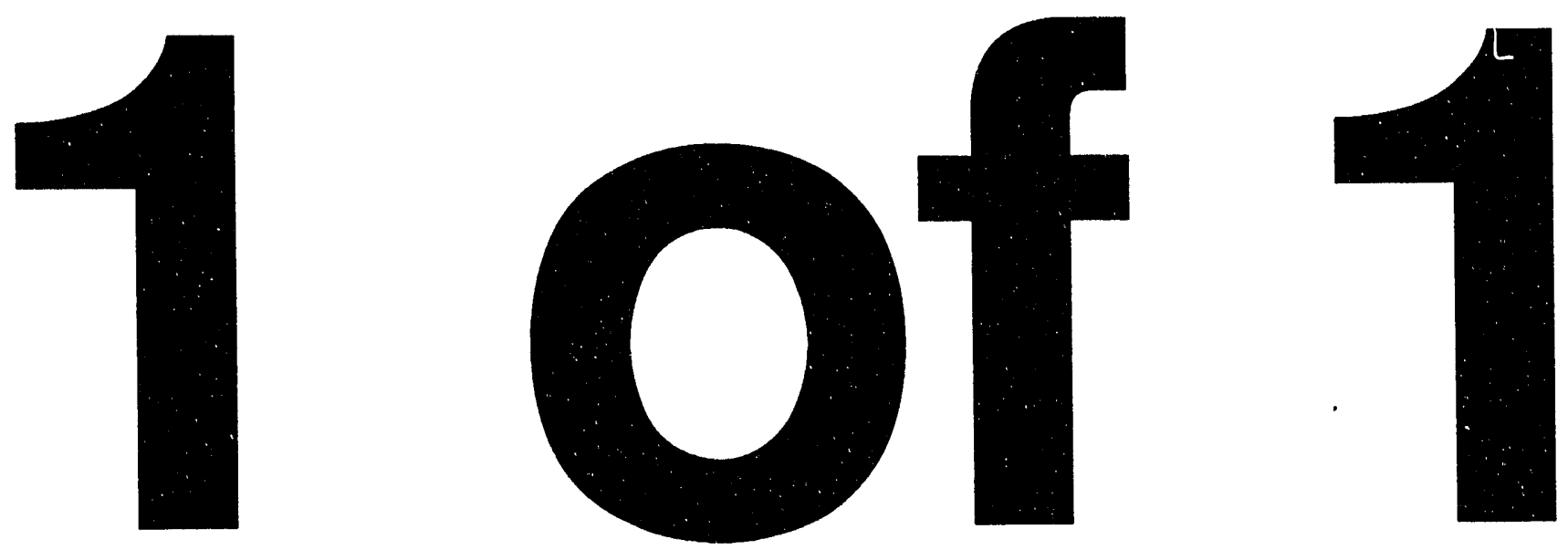


\title{
ADVANCED LIQUEFACTION USING COAL SWELLING \\ AND CATALYST DISPERSION TECHNIQUES
}

\author{
Report Number $: .02$ \\ Quarterly Technical Progress Report \\ Eor \\ january - March 1992
}

?roject Manager: D. C. CRONAUER

\author{
Principal Investigators: C. i. Curtis, \\ Auburn University \\ C. Gutterman, \\ FWDC \\ S. Chander, \\ Pennsylvania State Univ.
}

Work Performed Under Contract No. DE-AC22-91PC91051

For

$\because$. S. Department of Energy

Pitssburgh Energy Technology Center

?ittsburgin, Pennsylvania

\author{
By \\ Amoco Oil Company \\ Research \& Development Department \\ Post Office Box 400 \\ Naperville, IL 60566
}

\section{DISCLAIMER}

This report was prepared as an account of work sponsored by an agency of the United States Government. Neither the United States Government nor any agency thereof, nor any of their employees, makes any warranty, express or implied, or assumes any legal liability or responsibility for the accuracy, completeness, or usefulness of any information, apparatus, product, or process disclosed, or represents that its use would not infringe privately owned rights. Reference herein to any specific commercial product, process, or service by trade name, trademark, manufacturer, or otherwise does not necessarily constitute or imply its endorsement, recommendation, or favoring by the United States Government or any agency thereof. The views and opinions of authors expressed herein do not necessarily state or reflect those of the United States Government or any agency thereof. 


\section{DISCLAIMER}

This report was prepared as an account of work sponsored by the United States Government. Neither the United States nor any agency thereof, nor any of their employees, aakes any warranty, expressed or implied, or assumes any legal liability or responsibility for the accuracy, completeness, or usefulness of any information, apparatus, product, or process disclosed, or represents that its use mid infringe privateiv owned rights. Reference herein to any specific commercial product, process or service by trade name, mark, manufacturer, or otherwise, does not necessarily constitute or imply its endorsement, recommendation, or Eavoring by the United States Government or any agency thereof. The views and opinions of the dutiors expressed herein do not necessarily state or reilect those of the inized States Government or any agency thereof.

\section{EECHNICAL STATUS}

This technical report is being transmitted in advance of DOE review, and no further dissemination of publication will be made of the report without prior approval of the LOE Project/Program Manager. 
This report was prepared by the organization named below as an account of work sponsored by the United States Department of Energy (DOE). Neither DOE, members of DOE, the organization named below, nor any person acting on behalf of any of them: (a) makes any warranty, expressed or implied,

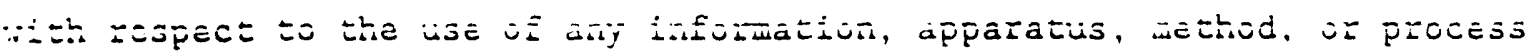
disclosed in this repore or that such use may not infringe privately owned rights; or (b) assumes any liabilities with respect to the use of , or for damages resulting from the use of, any information, apparatus, method, or process disclosed in this report.

?repared by

Anoco Oil Company (Amoco Corporacion)

:iaperville, Illinois 


\section{TABLE OF CONTENTS}

EXECUTIVE SUMMARY

PROGRAM OBJECTIVES

PROGRAM MILESTONES

SUMMARY OF RESUITS AND ACTIVITY

Subtask 1.1

Subtask 2.1

$\xi$

CONCLUSIONS AID FUTURE WORK

$\hat{\jmath}$

ACKNOWLEDGEMENT

APPENDIX 
Research in this projec centers upon developing a new approach to the direct liquefaction oz coal to produce an ail-distillate product slate at a sizable cost reduction over current technology. The approach integrates all aspects of the coai :iqueraction process including coal selection, pretreatment, coal sweiling with catalyst impregnation, coal liquefaction experimentation. product recover $y$ with characterization. alternate bottoms processing, and a technical assessment inciujing an economic evaiuation. The project is being carried out under contract to the United States Department of Energy.

The Department of Energy has not yet authorized starting the experimental aspects of this and other similar projects; specifically, approval of the Sational Environmental Eolicy Act (NEPA) requirements. Pervious work had cencered upon the following: 1) preparing and obtaining approval of the Project Management Plan. Ailestone Scheduie/Manpower Plan, Cost Plan, and the Notice of Energy RSD Project, 2) negotiating contracts to be signed with subcontractors after the NEPA approvals, 3) obtaining buik sampies of Eeedstocks for the project, 4) up-dating the background literature, and 三) preparing and testing a computer program to perform material balance caiculations for the continuous flow liquefaction unit.

There has been essentiaily no experimental activity during the current period due to the lack of having NEPA approval by DOE. A set of coai samples were sent to Hazen Research for beneficiation so that experimentation can get underway after DOE has approved the document. 
The objective of this eroject is to develop a new approach to the direct liquefaction of coal to generate an all-distillate product slate at a sizable cost reduction over current technology. The approach will integrate all aspects $0 \equiv$ the coal liquefaction process including coal selection, pretreatment, coal swelling with catalyst impregnation (and parallel runs with dispersed catalyst), sal liquefaction experimentation including solvent evailiation, product recovery with characterization, alternate bottoms processing, and a technical assessment including an economic evaluation. The three tasks of this program are:

1. Task 1: Laboratory-Scale Experimentation--The goals are to obtain samples of coals and Wilsonville-derived solvents and vacuum tower bottoms and to establish experimental procedures.

2. Task 2: Laborazory-Scale Dperation--The goals are to:

(1) reduce the concencration of mineral matter and alkali metals in low rank coals. 2) swell and impregnate coals with dispersed catalysts, (3) characterize the resulting catalyst solids, (4) evaluate the ejEectiveness of the procedures using liquefaction runs, and (5) stucy solids separation and alternative bottoms handling, which inciudes observing pumping characteristics, deasphalting and coiking.

3. Task 3: Technical Assessment-- The goals are to analyze the data, develop cescriptive models, and carry out an economic evaluation.

The research will be carried out in cooperation with the following subcontractors: Foster theeler Development Corporation. Auburn University, Zennsylvania State University, and Hazen Research Incorporated. Appropriate meetings and correspondence will be maintained to insure effective completion of the project. 
The first key milestone is to obtain the appropriate feed stocks for the experiments. The second milestone is preparing the beneficiated bulk samples of coal for subsequent experiments. The feedstocks have been obtained and the benericiation of samples of Martin Lake lignite and Black Thunder subbituminous coal is currently be done by Hazen Research, Inc.

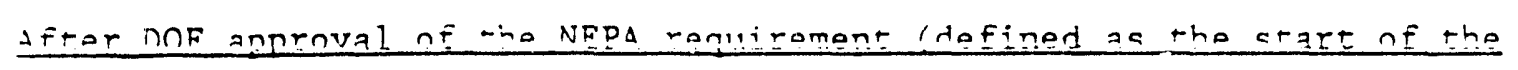
research program), the small-scale coal swelling and catalyst screenirg program will start. Sufficient data must be obtained from the latter program to establish conditions for bench-scale liquefaction experiments to start during the fourth quarter. The batch deasphalting and coking experiments will be completed by the end of the fifth quarter.

Experimentation should be essentially complete by the end of the seventh quarter in order to complete the project within a two year period after approval of the NEPA requirement. 
Activity has been limited to carrying out non-experimental work covered under Subtasks 1.1 and 2.2 .

\section{Subtask 1.1: Laboratory Support}

The following documentation has been completed as reported in the previous quarterly:

1) Project Management Plan,

2) Milestone Schedule/Manpower Plan,

3) Cost Plan,

4) Notice of Energy R\&D Project.

Draft copies were submitted to the DOE project manager. Dr. 3aird, and approval was received curing a joint meeting of December 4.

Eresh, bulk samples of 3lack Thunder subbituminous coal and Martin Lake Texas lignite are on-hand. Analyses have been obtained from Commerciai Testing Laboratories, inc. These anaiyses are attached in the Appendix.

Sufficient quantities of coal-derived liquids (atmospheric tower bottoms and solvent) have been obtained from wilsonville in order to complete this project. A bulk sample of Wilsonville atmospheric tower bottoms derived from the liquefaction of Black Thunder subbituminous coal has been sent to Foster wheeler Development Corporation so that it will be available when the start of experimentation is authorized by DOE.

The literature concerning coal swelling and coal liquefaction using dispersed catalysts has been up-dated using Amoco's library computer search facilities. 
Subtask 2.1: Laboratory Support

The material balance program for the continuous flow unit, AU-44, has been written for a moderate-sized PC in Lotus 123R22. This program has been cested using data generated under a previous DOE contract (DE-AC2238P(88819). A print-out of the spreadsheet was included in the previous quarterly.

Drum quantities of Martin Lake (Texas) lignite and Black Thunder subituminous coal have been sent to Hazen Research, Inc. for crushing, sizing ( $8 \times 60$ mesh and minus 60 mesh fines), aqueous $\mathrm{SO}_{2}$-treatment, and heavy-media (sink/float) separation. It has been requested that conditions for the heavy-media separation be chosen that results in a high recovery (about 858 ) of the float coal fractions. 
After approval of the NEPA form by the Department of Energy, experimentation is ready to get underway. Feedstocks have been obtained and the beneficiation of the feed coal will be complete. It is anticipated that a new schedule of experimentation will have to be drafted.

\section{ACKNOWLEDGMENTS}

This work is being supported by the United States Department of Energy under Contract DE-AC22-91PC91051. Appreciation is particularly extended to Mr. C. Gutterman of Foster Wheeler Development Corporation, Dr. C. W. Curtis of Auburn University, and Dr. S. Chander of Pennsylvania State University for participating in contract negotiations and preparing to initiate work in this project. 
APPENDIX I

ANALYSES OF SAMPLES OF THE MARTIN LAKE LIGNITE AND

BLACK THUNDER SUBBITUMINOUS COAL 
Eebruary 18, 1992

AMOCO RESTARCH CENTER

Warrenville Road \& Mill St.

P.O. Box 3011

Naporville, IL 60566

ATTN: D.C. Cronauer

Mail Station $\mathrm{H}-4$

\section{Rind of sample \\ reported to us Coal}

Sample taken at - - -

Sample taken by Amoco Research Center

Date sampled February 10,:992

Date received February 13, 1992
PLEASE AODRESS ALL CORPESPONDENCE TC :5130 VAN DRUNEN RD. P. P. BOX iZ SOUTH HOLLAND. IL 6047 TELEPHONE: (708) 331.29C FAX: (708) 333-3CE:

\section{Sample identification by} Anoco Research Center

Sample No: 14007-117-C2

Sample ID: Raw Coal - Black Thunder

Project No.: 70-6186-15

P.0. No. 099P25960

\section{PROXIMATE ANALYSIS}

As Receited Dry Basis

\section{Toisture}

2 Ash

2 Volatile

\& Eixed Carbon

Btu/1b

7 Sulfur

MAF Btu

6.89

41.86

31.06

$\frac{51.25}{100.00}$

11872

0.41

12751

\section{ULTIMATE ANALYSIS}

\section{As Received Dry Basis}

Ioisture

7 Carbon

7 Hydrogen

I Nitrogen

Z Sulfur

$z$ Asb

2 Oxygen(diff)
25.81

50.76

3.77

0.37

0.30

5.11

13.88

$\frac{13.88}{100.00}$ $\operatorname{xxxxx}$

68.42

5.08

0.50

0.41

6.89

18.70

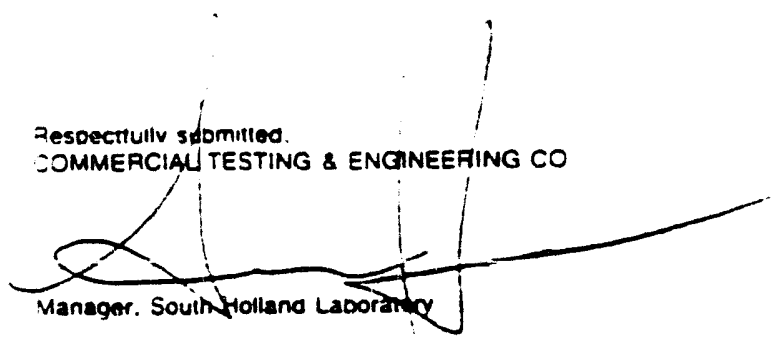

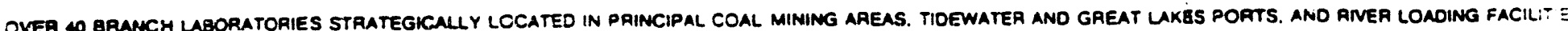


February 18, 1992

AMOCO RESEARCH CENTER

Warrenville Road \& Mill St.

P.0. Box 3011

Naperville, IL 60566

ATTN: D.C. Cronauer

Mail Station $\mathrm{H}-4$

Kind of sample

reported to us Coal

Sample taken at -----

Sample taken by Amoco Research Center

Date sampled February 10, 1992

Date received Eebruary 13,1992
PLEASE ADDRESS ALL CORAESPONDENCE TC 16130 VAN ORUNEN RO., P.O. $80 X 12 i$ SOUTH HOLLAND. IL 60473 TELEPHONE: (708) 331.2900

FNX: (708) 333-306C

Sample identification by Anoco Research Center

Sample No: 14007-116-C4

Sample ID: Raw Coal - Lignite

Project No.: 70-6186-15

?.0. No. 099P25960

Analysis Report No. 71-27774

PROXIMATE ANALYSIS

As Received Dry Basis

\begin{tabular}{|c|c|c|}
\hline $\begin{array}{r}\text { Moisture } \\
\text { \ Ash } \\
\text { ₹ Volatile } \\
\text { / Eixed Carbon }\end{array}$ & $\begin{array}{r}34.83 \\
6.92 \\
30.18 \\
28.07 \\
100.00\end{array}$ & $\begin{array}{r}x \times x \times x \\
10.62 \\
46.31 \\
43.07 \\
100.00\end{array}$ \\
\hline $\begin{array}{r}\text { Btu/1b } \\
\text { = Sulfur } \\
\text { MAF Btu }\end{array}$ & $\begin{array}{l}7367 \\
1.30\end{array}$ & $\begin{array}{r}11304 \\
1.99 \\
12647\end{array}$ \\
\hline
\end{tabular}

\section{ULTIMATE ANALYSIS}

As Received Dry Basis

\begin{tabular}{|c|c|c|}
\hline $\begin{array}{r}\text { I Moisture } \\
\text { Z Carbon } \\
\text { \% Hydrogen } \\
\text { \% Nitrogen } \\
\text { / Sulfur } \\
\text { I Ash } \\
\text { Xygen (diff) }\end{array}$ & $\begin{array}{r}34.83 \\
42.13 \\
3.15 \\
0.80 \\
1.30 \\
6.92 \\
10.87 \\
100.00\end{array}$ & $\begin{array}{r}\operatorname{zxxxx} \\
64.64 \\
4.84 \\
1.23 \\
1.99 \\
10.62 \\
16.68 \\
100.00\end{array}$ \\
\hline
\end{tabular}

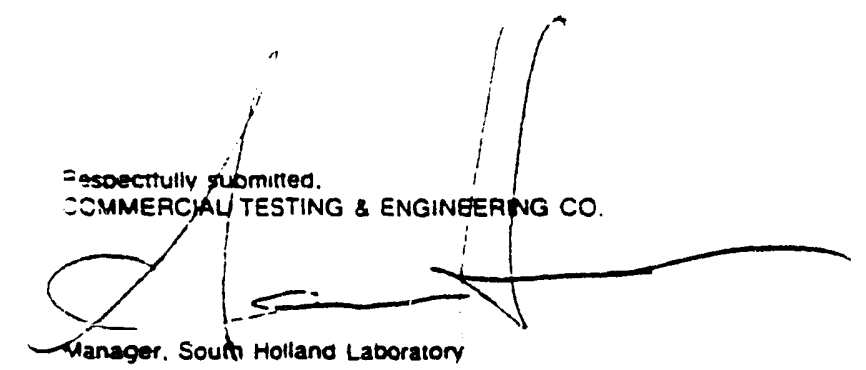

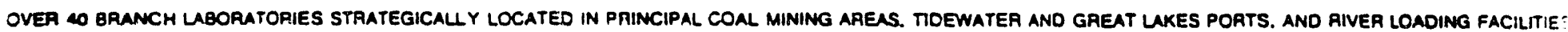



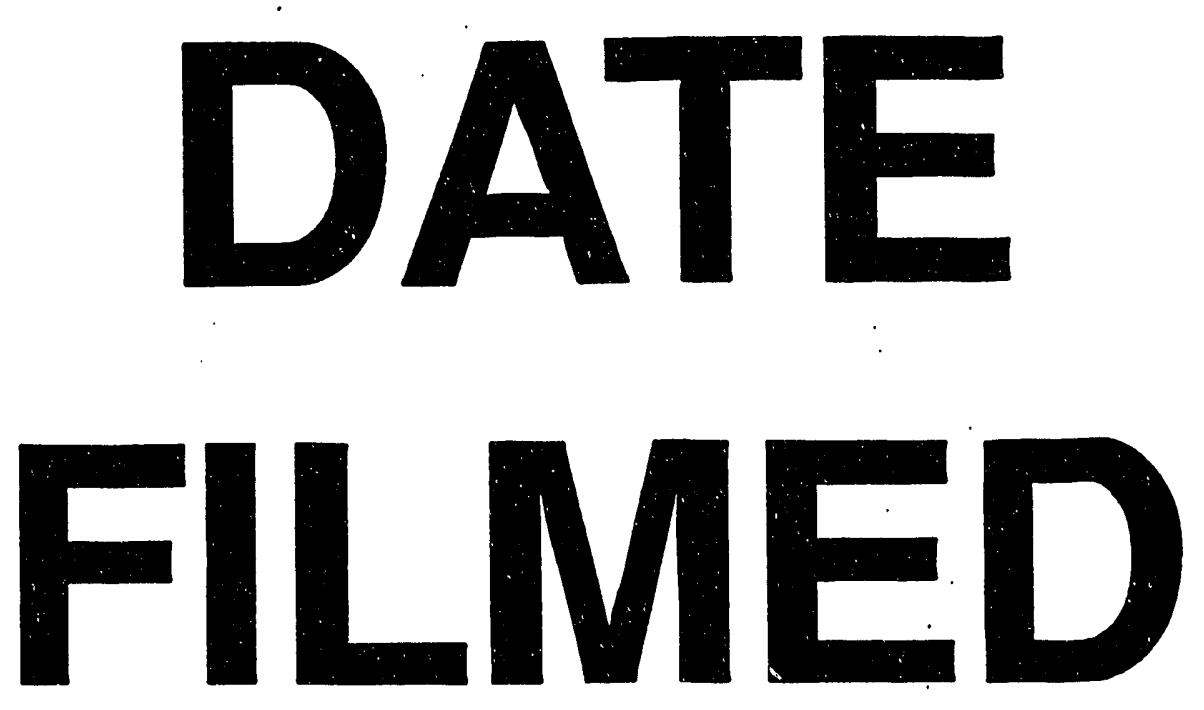

$9 / 9 / 93$
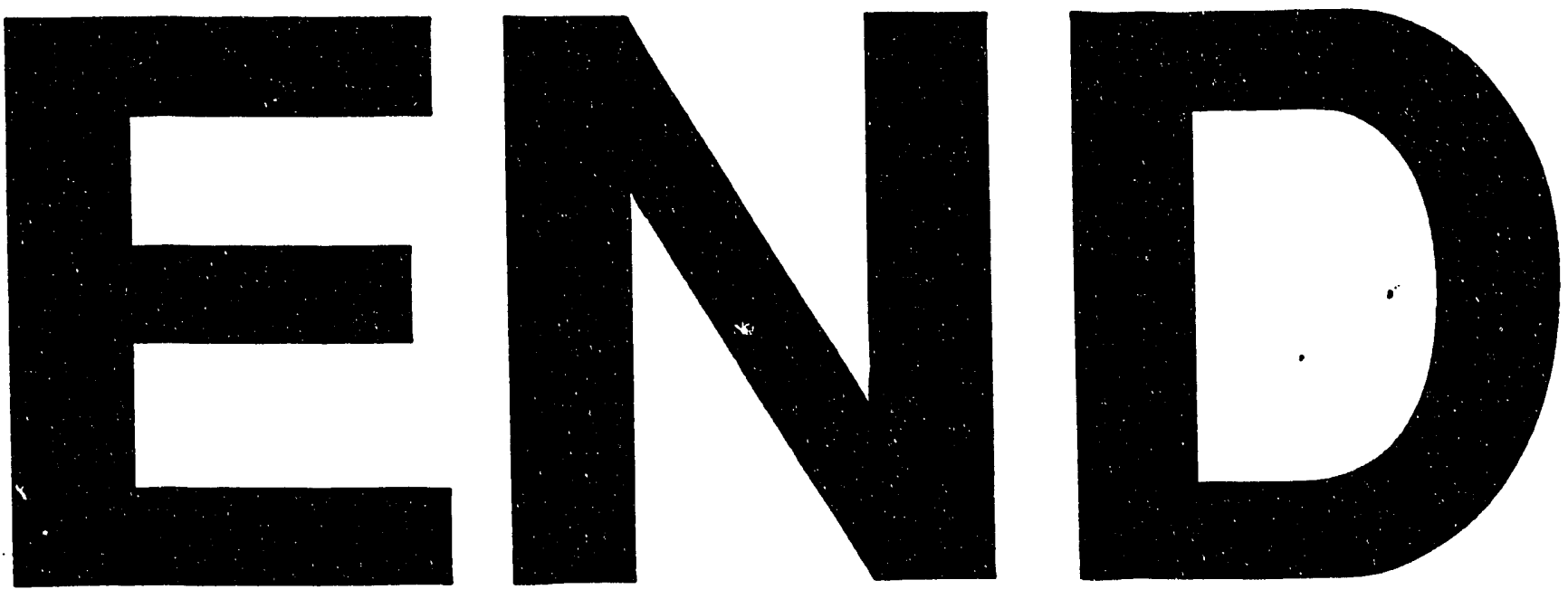
